Radovan Bacik,

Ph.D., Associate Professor, University of Presov in Presov, Slovakia

(iD) ORCID ID, 0000-0002-5780-3838

email: radovan.bacik@unipo.sk

Beata Gavurova,

Ph.D., Professor, Technical University of Kosice, Slovakia

(iD) ORCID ID, 0000-0002-0606-879X

email: beata.gavurova@tuke.sk

Richard Fedorko,

Ph.D., Associate Professor, University of Presov in Presov, Slovakia

(iD) ORCID ID, 0000-0003-3520-1921

email: richard.fedorko@unipo.sk

Maria Olearova,

University of Presov in Presov, Slovakia

(iD) ORCID ID, 0000-0001-9086-7975

email: maria.olearova@smail.unipo.sk

Correspondence author: beata.gavurova@tuke.sk

\title{
USING DIGITAL DEVICES IN THE PROCESS OF ONLINE SHOPPING: A STUDY OF DEMOGRAPHIC DIFFERENCES
}

\begin{abstract}
The paper deals with the investigation of the analysis that reveals the impact of digitalization as the development of new communication platforms, which are also changing the consumer's purchasing behaviour in the online environment. The main goal of this research is to identify consumer preferences concerning the communication platforms of digital equipment for purchasing in the online environment. The study is focused primarily on smartphones, tablets, phablets, laptops, PDAs and desktops. The survey sample amounts to 414 respondents. The authors observed the differences in preferences on types of digital devices based on the sex, generations, the level of education of respondents and the frequency of the purchase. Methodological tools of this study are non-parametric tests and ordinal regression analysis. The analysis results stated that the most preferred device for the online purchase is the notebook as for males and so for females. Herewith, the authors did not find statistically significant gender differences. It is expected that the impact of innovation various changes in these preferences, especially in a change to use tablets and smartphones. The analysis has shown that people mostly purchase via the smartphone. Moreover, they are the customers with a higher frequency of purchases, and customers of generation $X$, which means that even the older consumers. The paper includes practical implications, particularly for business entities, for the reason that knowledge of the options leads to the right set of strategies and will follow the effective achievement of business aims. Businesses with the characteristics of an innovative and active entity have a much greater chance of becoming a prosperous company. These companies are able to respond flexibly to the values of those consumers who are using their digital devices. The ever-increasing global interest in digital shopping signals the urgent need to deepen knowledge of consumer behaviour.
\end{abstract}

Keywords: digital devices, E-commerce, online shopping, Slovakia, generation, regression analysis, nonparametric methods.

Introduction. The paper focuses on a thorough analysis to find an answer that which factors influence the new digital devices for consumer behaviour in the online environment. Based on a defined problem, the main objective of this research is to identify the dynamics of consumer preferences concerning digital devices used for purchasing in the online environment. Various researches are dealing with mobile

Cite as: Bacik, R., Gavurova, B., Fedorko, R., \& Olearova, M. (2020). Using Digital Devices in the Online Shopping: a Study of Demographic Differences. Marketing and Management of Innovations, 4, 154-167. http://doi.org/10.21272/mmi.2020.4-12 
purchasing, but most of them are more concerned with intentions and attitudes rather than with practice (Fuentes et al., 2017). The studies examined the issue of mobile technology adoption (Agrebi and Jallais, 2015; Groß, 2015a; Yang, 2012) and examined what incentives drive consumers to mobile purchase (Li et al., 2012; Yang and Kim, 2012) or how consumers react to mobile marketing (Goh et al., 2015, Pescher et al., 2014; Sultan et al., 2009) as well as links with business performance increase due to online technologies usage (Hu et al., 2019; Mishchuk et al., 2016; Roudposhti et al., 2018).

Although there is a particular interest in mobile purchasing, there are sharp differences between buying through smartphones and computers. Goh et al. (2015) have found that consumer behaviour in searching for information through smart mobile devices differs from searching for information through desktop computers. Mobile users, for example, read content intermittently, because the content is displayed on smaller screens. Therefore, there are obvious limitations in the use of smart mobile devices, not only because of the small screen but also because of the limited computing power (Mifsud, 2004). Ghose et al. (2013) have found a similar result that smaller screens on smart mobile devices increase the difficulty of searching. However, it affects the relative attractiveness of the first search result compared to the search results in computers.

Smart mobile devices are relatively innovative digital devices with fast market penetration compared to PCs/laptops (Deloitte, 2014). From the point of view of the process of adopting innovation, it is worth mentioning the framework for adoption of innovations by Rogers (2003) consisting of Knowledge, Persuasion, Decision, Implementation and Confirmation. Based on this model, the acceptance of innovation is affected by different psychological factors but also by social or cultural environments, and the results may be other preferences regarding the use of digital devices. The reasons are generational differences, lifestyle, social status or perceptual abilities of the individual, as well as the impact of mass media and social trends.

One of the decisive factors influencing the choice of digital devices to implement online activities is user comfort (Almeida et al. 2019). From the consumer point of view, if people are at home, they prefer more comfort and plenty of time to perform online activities. While away from home, they appreciate the possibility of continually connecting to the Internet, which makes it possible to search for the information needed at any time and practically anywhere. Based on this, a whole range of digital devices is used throughout the consumer sales journey. It depends on the consumer's personal user preferences, whether their purchase is made (final step) through a mobile device or a traditional PC or Notebook.

As mentioned above, some studies confirm the interest in mobile purchasing. However, there are no studies on the question of which digital devices in terms of screen size (smartphone, tablet, notebook or desktop) are preferred by men and women when purchasing in the online environment. This contribution aims to broaden the knowledge in the selected area and to find out whether there is such an interest in mobile purchasing even when comparing with other digital devices. The results of this analysis suggest that the difference in the use of digital devices to buy products in the online environment is not statistically significant from a gender perspective. For this reason, it was the partial goal to find out for which variables (age, education and frequency of purchase) these differences were observable. However, the problem of this analysis is related to the need to analyze the impact of factors for selecting individual digital devices. This problem may be the subject of further scientific research. The presented article lists a review of the literature to approach the issue of e-commerce theoretically from the perspective of previous studies. The following section provides an overview of the methods used in this research. Besides, the research questions and research hypotheses were formulated. In turn, they are statistically verified in the next part of this article. In the last part of the article, there is a discussion on the results and provides several managerial implications for improving e-commerce.

Literature Review. The emergence and development of Internet technologies have expanded the business into new areas, with the so-called modern "e-commerce". Online purchasing becomes a daily 

Differences

part of most people's lives, and it cannot be perceived as a hobby (Doherty and Chadwick, 2010). Many scientists have defined e-commerce in their perspective. In general, the term e-commerce is defined as performing economic activities using an electronic connection (Paynter and Lim, 2001; Osman et. al.,2010, Haque et al.,2011). Gefen (2002) however, provides a more detailed definition of e-commerce that uses the Internet and www as technology infrastructure for communication, distribution and exchange of information, which then leads to business transactions between retailers and consumers.

In the frame of this study, e-commerce is considered to be a system allowing a direct connection of key business entities. i.e. between the seller and customer. Herewith, this system is aimed to make their business relationships more attractive, using electronic networks to enable day-to-day business activities such as payments or delivery of goods and providing the service (Bhasker, 2013; Bacík et al., 2014). It could be added that e-commerce is not limited to make purchases or sales of goods. E-commerce is a whole range of digital technologies that enable electronic communication (Chaffey, 2009; Stefko et al., 2010). E-commerce has provided many new opportunities for consumers (Hajli, 2014). The rapid expansion of the Internet, e-commerce and social media have made the study of consumer behaviour in e-commerce and fundamental research agenda (Liang and Turban, 2011). E-commerce and social media are likely to develop marketing strategies through trust-building mechanisms and affecting customers' intention to purchase online products. The rapid growth of e-commerce raises important research questions about the levels of loyalty and churn management in the online environment. This rapid growth reflects the compelling advantages that e-commerce and social media offer over conventional physical stores, including easier interconnectivity and participation on the web (Mueller et al., 2011). Nowadays, the company is willing to accept new technologies. Undoubtedly, digital devices, exceptionally smart mobile devices, are significant for day-to-day operations (Islam et. al., 2013). Over the past two decades, mobile devices have had a profound impact on everyday life. At the same time, the retail sector has seen the enormous potential of mobile technology, which was the beginning of the rapid development of mobile purchasing (Groß, 2015b), as smartphones are, according to many scientists, ubiquitous shopping opportunities (Bang et al., 2013; Chong, 2013). According to DESI (2020), 71\% of Europeans already use transactional activities on the Internet, such as shopping. It should note that it is more by 3\% than in 2017.

The latest Global Web Index survey (2017) confirmed the changing consumer behaviour concerning online purchasing because users rather prefer smart mobile devices instead of PC's/laptops. The Statista statistical portal (2017) stated that consumers are visiting online stores and gaining more information about the product via smartphones than desktops. Still, executed orders are recorded more on desktops than smartphones. Many scientists say that recently gender is the most influential factor affecting the general use of the Internet (Hwang et. al., 2006; Jackson et al., 2008; Potosky, 2007; Zhang, 2005). Consumer purchasing behaviour has seen significant gender gaps that are also related to different online purchasing behaviour (Bae and Lee, 2011). However, some academics claim that gender gaps in e-commerce during purchasing do not exist (Goldsmith and Goldsmith, 2002; Kaplan, 2011). Several studies have reported that men have a significantly more positive attitude towards new technologies compared to women (Mitra et al., 2005; Zhou et al., 2007). A study by Hart et al. (2007) found that men have poor shopping experience during the purchase and therefore prefer an online environment for purchasing. Further research has pointed out that men tend to try new things, while women prefer traditional methods (Doolin et. al., 2005).

Based on the studies mentioned above and analyzes that demonstrate significant gender gaps in consumer behaviour in online shopping, it is expected that the preferences of digital devices used to buy products in the online environment are different between men and women. Based on these arguments, in the following part of the contribution of the defined hypothesis, there is statistical verification of the claims.

Methodology and research methods. The main goal of the research is to identify the homogeneity of consumer preferences concerning digital devices when purchasing in the online environment. Based on the main goal of this research, the following research questions and the main research hypotheses 
were formulated.

R.Q.I Is there a difference between the output preferences of digital devices for purchasing products in the online environment?

$\mathrm{H} 1$ : It is expected a significant difference in the preferences of digital devices for purchasing goods in online stores.

R.Q.II Is there a difference in the preferences of men and women in using the selected digital devices for purchasing products?

$\mathrm{H} 2$ : The gender differences in using the smartphone to buy products in the online environment are statistically significant.

H3: The gender differences in using the tablet to buy products in the online environment are statistically significant.

H4: The gender differences in using the laptop to buy products in the online environment are statistically significant.

H5: The gender differences in using the desktop to buy products in the online environment are statistically significant.

R.Q.III Is there a difference in the impact of education categories, purchase frequency in the usage of smartphones?

H6: It is expected a significant difference in the impact of education categories in the preference of purchasing via the smartphone.

$\mathrm{H7}$ : It is expected a significant difference in the purchase frequency impact in the preference of purchasing via the smartphone.

H8: It is expected a significant difference in the age category (generation) in the preference of purchasing via the smartphone.

In terms of data collection, this research is characterized as primary, while as interdisciplinary concerning the interconnection of different disciplines. In the case of theoretical outcomes, this research could be regarded as applied and practical and, given its character, it is possible to talk about quantitative research. For meeting the defined research goal, it was conducted a questionnaire survey throughout the Slovak Republic during the period between February 2016 and June 2016. The survey was carried out in the form of an electronic questionnaire. It could be characterized by randomized and stratified selection with characteristics of the basic set of gender and age. Herewith, respondents in terms of age cohorts were divided into consumers of so-called generations $X$ and $Y$. An email database of students and employees of the University of Presov was used to send out the questionnaires. Psychologists and sociologists have different opinions on the exact limitation of these generations. According to Arsenault (2004) and Hill (2002) in Klepochova and Kopanicova (2012), the age cohort, known as Generation X, is born when people in the western world had a post-war populism boom, which means that they are people born in the 60s and 70s of the 20th century. However, Kotler \& Armstrong (2004) in Klepochova and Kopanicova (2012) defines Generation X with the years 1965-1976. On the other hand, according to a new article written by Kozacka (2014), who is a sociologist and psychologist, Generation X is a group of people born between 1964 and 1981. In addition, he characterizes it as a group of individualistic and impersonal people with the need for freedom and informality, and who are often sceptical but also able to welcome new technologies. Millennials (also known as Generation $Y$ ) are the generational demographic cohort following Generation X. It is also called as «The Net Generation», or even «Echo Boomers». They add that according to many authors, it started after the Generations X in the 1980s. However, the researchers disagree on when this generation ends. For example, Kotler and Armstrong (2004) in Klepochova and Kopanicova (2012) state that people born in the 90s of the 20th century are part of the Generation Y. Others, however, claim that children born until 2000 are also a part of this generation (Arsenault, 2004 in Klepochova and Kopanicova, 2012). 

Differences

On the contrary, Kozacka (2014) does not mark the boundaries of this generation. He claims that they are people born after 1981. In this group, it is often encountered the view that this online generation is strongly influenced by the Internet and social networks for which technology is an indispensable part of their lives. Based on the above statements by various authors, this study categorizes a sample of respondents on Generation Y, i.e. people from the age of 16 to 35, and Generation X, which includes respondents from the age of 36 to 52 . The effort was to achieve a ratio of $53 \%$ in the case of women, and the rest should be filled out by men, but the willingness to fill out the questionnaire by women was significantly higher. The younger generation (Generation $Y$ ) has also attended mainly in the survey with a $72 \%$ share. At the same time, respondents from the older generation (Generation X) were significantly less, only $28 \%$. Due to incomplete completion, 23 observations were excluded. The selection set consists of 414 observations, of which approximately $63 \%$ were women. These data reflect the status of students at Slovak universities in terms of gender (MSVVS SR, 2018). The obtained data were evaluated using the Microsoft Office suite, namely the Excel spreadsheet editor. In the frame of this study, the IBM SPSS Statistical Software allowed processing mathematical and statistical analyzes. Due to the scale of the questionnaire, non-parametric methods were used within those methods. The first research question was analyzed with the Kruskal-Wallis $\mathrm{H}$ test, for the second research question, the Mann-Whitney $\mathrm{U}$ test was used, and the third research question was analyzed by ordinal regression analysis. According to Stevens' methodology, this survey questions relevant, due to their nature, were included in the nominal and ordinal level of data. The study refers to the nominal levels of data in identifiers. The included variables are gender, education, frequency of purchasing (LOW - a few times a year, HIGH - several times a week to several times a month) and age - generation. These variables were dichotomically categorized variables. The following charts visualize the ratios of each variable category.
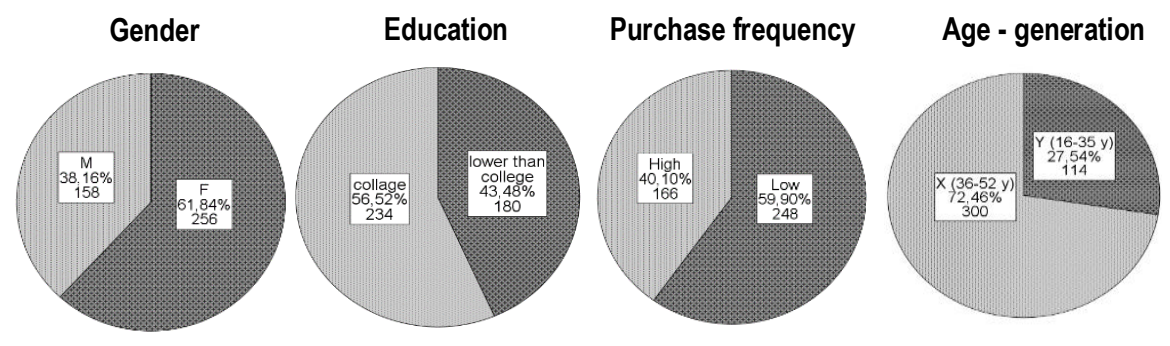

Figure 1. Identification variables

Sources: developed by the authors.

The surveyed variables were designed in a 5-degree ordinal symmetric scale (ever, rarely, occasionally, often, always), through which it was identified preferences for digital devices such as smartphones, tablets, phablet, PDAs and desktop. The following table shows the results of the collected data of the variables.

Table 1. Frequency analysis of detection variables

\begin{tabular}{lcccccccccccc}
\hline & \multicolumn{3}{c}{ Smartphone } & \multicolumn{2}{c}{ Tablet } & \multicolumn{2}{c}{ Phablet } & \multicolumn{2}{c}{ Notebook } & \multicolumn{2}{c}{ PDA } & \multicolumn{2}{c}{ Desktop } \\
& $\mathbf{N}$ & $\mathbf{\%}$ & $\mathbf{N}$ & $\mathbf{\%}$ & $\mathbf{N}$ & $\%$ & $\mathbf{N}$ & $\%$ & $\mathbf{N}$ & $\%$ & $\mathbf{N}$ & $\%$ \\
\hline ever & $\mathbf{2 3 6}$ & $57,0 \%$ & $\mathbf{2 7 4}$ & $66,2 \%$ & $\mathbf{3 7 8}$ & $91,3 \%$ & $\mathbf{7 2}$ & $17,4 \%$ & $\mathbf{3 8 6}$ & $93,2 \%$ & $\mathbf{2 6 0}$ & $62,8 \%$ \\
rarely & $\mathbf{2 2}$ & $5,3 \%$ & $\mathbf{1 6}$ & $3,9 \%$ & $\mathbf{6}$ & $1,4 \%$ & $\mathbf{1 8}$ & $4,3 \%$ & $\mathbf{6}$ & $1,4 \%$ & $\mathbf{1 6}$ & $3,9 \%$ \\
occasionally & $\mathbf{3 0}$ & $7,2 \%$ & $\mathbf{3 4}$ & $8,2 \%$ & $\mathbf{1 4}$ & $3,4 \%$ & $\mathbf{1 0}$ & $2,4 \%$ & $\mathbf{6}$ & $1,4 \%$ & $\mathbf{2 2}$ & $5,3 \%$ \\
often & $\mathbf{3 4}$ & $\mathbf{8}, 2 \%$ & $\mathbf{3 6}$ & $8,7 \%$ & $\mathbf{6}$ & $1,4 \%$ & $\mathbf{3 0}$ & $7,2 \%$ & $\mathbf{6}$ & $1,4 \%$ & $\mathbf{2 2}$ & $5,3 \%$ \\
always & $\mathbf{9 2}$ & $22,2 \%$ & $\mathbf{5 4}$ & $13,0 \%$ & $\mathbf{1 0}$ & $2,4 \%$ & $\mathbf{2 8 4}$ & $68,6 \%$ & $\mathbf{1 0}$ & $2,4 \%$ & $\mathbf{9 4}$ & $22,7 \%$ \\
\hline
\end{tabular}

Sources: developed by the authors. 
R., Bacik, B., Gavurova, R., Fedorko, M., Olearova. Using Digital Devices in the Online Shopping: a Study of Demographic Differences

Results. For providing a complete view of the data analyzed in the first step of this section, this paper presents a comprehensive Table 2 of frequency analysis of digital device preferences based on the identification variables.

Table 2. Frequency analysis of detection variables/identification

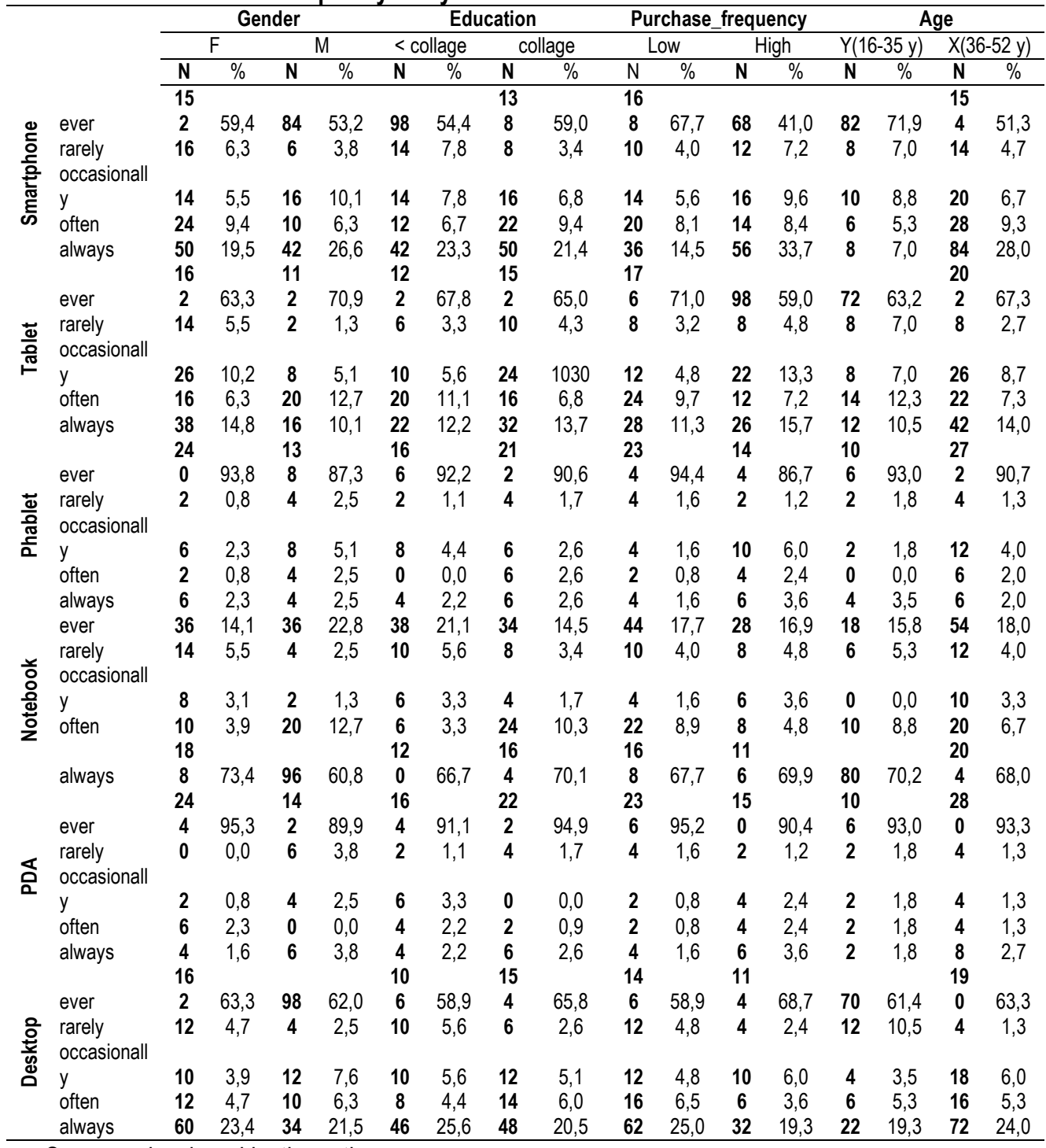

Sources: developed by the authors.

Homogeneity of digital devices when purchasing at overall.

$\mathrm{H} 1$ : it is expected a significant difference in the preferences of digital devices used for purchasing goods in online stores.

The following Table 3 informs about a significant difference in the preference of individual devices 

Differences

used for purchasing online. The analysis of these assumptions is conditional on the hypothesis:

$\mathrm{H} 1$ : it is expected a significant difference in the preferences of digital devices used for purchasing goods in online stores.

Table 3. Analyzing the homogeneity of using digital devices when purchasing

\begin{tabular}{cc}
\hline Test Statistics ${ }^{\text {a.b }}$ & Rate of preferences \\
\hline Chi-Square & 785,780 \\
df & 5,000 \\
Asymp. Sig. & 0,000
\end{tabular}

a. Kruskal Wallis Test

Sources: developed by the authors.

From the results of the analysis, it is evident that the $p$-value is equal to zero. The above output allowed concluding that there are statistically significant differences in the preferences of individual devices when shopping online. This opinion recommends accepting the basic $\mathrm{H} 1$ hypothesis.

It is possible to divide the output of individual device preferences into three groups. The notebook enjoys the highest popularity. The smartphone, tablet and desktop group is less preferred. The phablet and PDA got the lowest popularity rate when purchasing online.

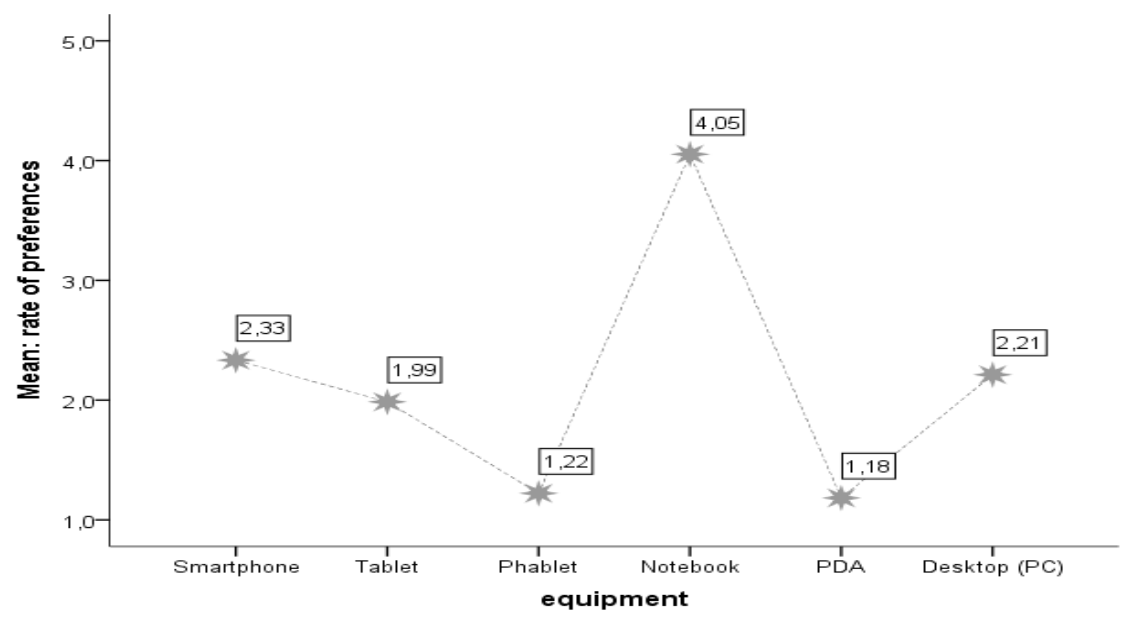

Figure 2. Visualization rate of preferences for digital devices when purchasing Sources: developed by the authors.

Homogeneity of digital devices when purchasing in the case of women and men. The results of this analysis also point that in the case of men and women the notebook is the most preferred one. However, Chart 2 demonstrates that the second most preferred device for men is the smartphone $(26.58 \%)$, while women prefer desktop (23.44\%) rather. However, according to Table 2, it is worth pointing out that, after counting the positive answers (4 and 5), it could assert that even for women, the second most frequently used digital device for online purchasing is the smartphone. The respondents' answers to the question: «Which digital devices do you use for purchasing online?» are below. 
R., Bacik, B., Gavurova, R., Fedorko, M., Olearova. Using Digital Devices in the Online Shopping: a Study of Demographic Differences

Table 4. Preferred devices for online purchasing/gender

\begin{tabular}{lcccccccccc}
\hline \multirow{2}{*}{ Digital devices } & \multicolumn{2}{c}{ 1-definitely no } & \multicolumn{2}{c}{2} & \multicolumn{2}{c}{3} & \multicolumn{2}{c}{4} & \multicolumn{2}{c}{ 5- definitely yes } \\
\cline { 2 - 10 } & Female & Male & Female & Male & Female & Male & Female & Male & Female & Male \\
\hline Smartphone & $59,38 \%$ & $53,16 \%$ & $6,25 \%$ & $3,80 \%$ & $5,47 \%$ & $10,13 \%$ & $9,38 \%$ & $6,33 \%$ & $19,53 \%$ & $26,58 \%$ \\
Tablet & $63,28 \%$ & $70,89 \%$ & $5,47 \%$ & $1,27 \%$ & $10,16 \%$ & $5,06 \%$ & $6,25 \%$ & $12,66 \%$ & $14,84 \%$ & $10,13 \%$ \\
Notebook & $14,06 \%$ & $22,78 \%$ & $5,47 \%$ & $2,53 \%$ & $3,13 \%$ & $1,27 \%$ & $3,91 \%$ & $12,66 \%$ & $73,44 \%$ & $60,76 \%$ \\
Desktop & $63,28 \%$ & $62,03 \%$ & $4,69 \%$ & $2,53 \%$ & $3,91 \%$ & $7,59 \%$ & $4,69 \%$ & $6,33 \%$ & $23,44 \%$ & $21,52 \%$ \\
\hline
\end{tabular}

Sources: developed by the authors.

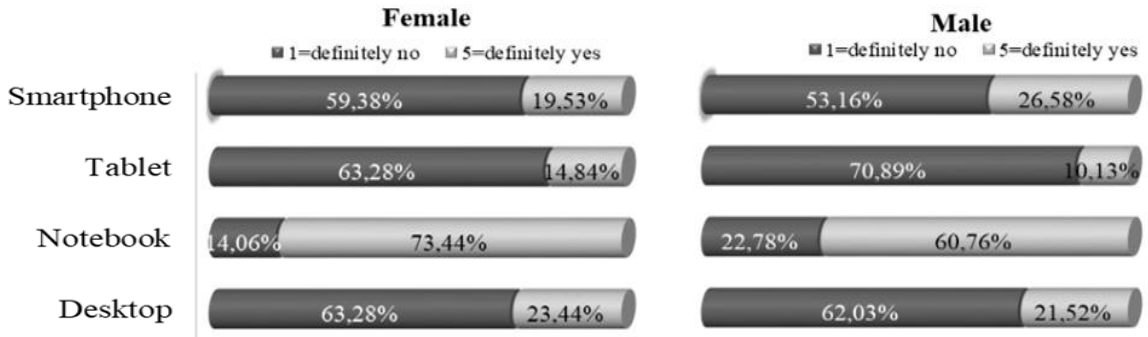

Figure 3. Preferred devices for online purchasing/gender

Sources: developed by the authors.

The non-parametric simultaneous testing of parallel profiles was used to investigate the verification of hypothesis 2 . The following table determines the mean and standard deviation values defined for the sample under investigation.

Table 5. Average and standard deviation values in the use of purchasing equipment Which digital devices do you use for purchasing in online stores

\begin{tabular}{llrrrr}
\hline Gender & & Smartphone & Tablet & Notebook & Desktop \\
\hline \multirow{2}{*}{ Female } & Mean & 2,23 & 2,04 & 4,17 & 2,20 \\
& Std. Deviation & 1,65 & 1,53 & 1,49 & 1,71 \\
\multirow{2}{*}{ Male } & Mean & 23,49 & 1,90 & 3,86 & 2,23 \\
\multirow{2}{*}{ Total } & Std. Deviation & 1,75 & 1,48 & 1,66 & 1,69 \\
& Mean & 2,33 & 1,99 & 4,05 & 2,21 \\
& Std. Deviation & 1,69 & 1,51 & 1,57 & 1,70 \\
\hline
\end{tabular}

Sources: developed by the authors.

It is not possible to clearly state from those mentioned above that the use of equipment for purchasing in the case of men and women is different. It could be seen that there are only minimal differences. In the highest proportion, women use notebooks. The following table shows us the results of each test. It was carried out the tests on the hypotheses of the second research question:

$\mathrm{H}$ 2: The gender differences in using the smartphone for purchasing products in the online environment are statistically significant.

H3: Gender differences in using the tablet for purchasing products online are statistically significant.

$\mathrm{H} 4$ : Gender differences in using the laptop for purchasing products online are statistically significant.

$\mathrm{H} 5$ : Gender differences in using the desktop for purchasing products online are statistically significant. 
R., Bacik, B., Gavurova, R., Fedorko, M., Olearova. Using Digital Devices in the Online Shopping: a Study of Demographic Differences

Table 6. Test output - Which digital devices do you use for purchasing products in online stores?

\begin{tabular}{lrrrr}
\hline & Smartphone & Tablet & Notebook & Desktop \\
\hline Mann-Whitney U & 18662 & 18914 & 17740 & 20106 \\
Wilcoxon W & 51558 & 31475 & 30301 & 53002 \\
Z & -1.474 & -1.318 & -2.563 & -0.116 \\
Asymp. Sig. (2-tailed) & 0.140 & 0.188 & 0.100 & 0.908 \\
\hline
\end{tabular}

Sources: developed by the authors.

It follows that in almost all cases, the level of $p$ is higher than 0.05 and therefore, the difference is not significant. The only difference was in the case of the notebook where the $p$-value was 0.01 . From the table above, it could be concluded that women preferred the laptop (4.17), which is significantly higher than in the case of men (3.86). The reason why women prefer laptops more than men may be their more serious concerns about the lack of display of products searched through smaller screens. The $\mathrm{H} 2, \mathrm{H} 3$ and $\mathrm{H} 4$ hypotheses were rejected based on the above outputs, while the hypothesis $\mathrm{H} 4$ was accepted, which states a significant difference of preferences between men and women. The impact of the age category, education, purchasing frequency in the preference for purchasing via smartphones in the online environment. It was assumed that the most significant innovation potential was in the preference of buying via the smartphone. Thus, there is an analysis of this tool in more detail and quantify the links resulting from the generation, education, and purchasing frequencies. The ordinal regression analysis was used to analyze these links. The application of the mentioned method is conditional on proportional odds, which was verified through the Parallel Lines test with a 0.066 significance output. This value is higher than 0.05 , so it was considered the condition to be fulfilled.

The second very important condition is the absence of multi-collinearity. The study has verified this condition and received the VIF outcomes for education 1.009, for purchasing frequency 1.061 and for age (generation) 1.069. All outputs are less than 10, so this condition was considered to be fulfilled. The following table lists the model output test. As the $p$-value is less than 0.05 , the model was considered significantly effective. Moreover, the Goodness-of-Fit tests were used with less than 0.05 outputs to analyze model efficiency, i.e. with a negative output of efficiency. However, as the Model Fitting Information Table shows positive outputs, the model was considered to be sufficiently effective.

Table 7. Model fitting information - ordinal analysis model

\begin{tabular}{lcccc}
\hline Model & -2 Log likelihood & Chi-Square & df & Sig. \\
\hline Intercept Only & 174.879 & & & \\
Final & 131.222 & 43.656 & 3 & 0.000 \\
\hline
\end{tabular}

Link Function: Logit.

Sources: developed by the authors.

The addition to the reliability analysis is the Pseudo R2 determined by the Nagelkerke method. The Nagelkerke output is equal to 0.110 . An $11 \%$ independent variable explains the variability of the dependent variable. The following table shows the outcomes of ordinal regression analysis. The analysis was carried out based on the third research question, in the description of the hypothesis:

H6: It is expected a significant difference in the impact of the category of education in the preference for purchasing via smartphones.

$\mathrm{H7}$ : It is expected a significant difference in the impact of the purchasing frequency in the preference for purchasing via smartphones.

H8: It is expected a significant difference in the impact of age categories (generation) in the preference for purchasing via smartphones. 
R., Bacik, B., Gavurova, R., Fedorko, M., Olearova. Using Digital Devices in the Online Shopping: a Study of Demographic Differences

Table 8. Parameter estimates - ordinal analysis model

\begin{tabular}{|c|c|c|c|c|c|c|c|c|c|}
\hline \multirow{2}{*}{\multicolumn{2}{|c|}{ Parameter }} & \multirow[b]{2}{*}{$\beta$} & \multirow[b]{2}{*}{$\begin{array}{l}\text { Std. } \\
\text { Error }\end{array}$} & \multicolumn{2}{|c|}{ Interval } & \multicolumn{3}{|c|}{ Hypothesis Test } & \multirow[b]{2}{*}{$\operatorname{Exp}(\beta)$} \\
\hline & & & & Lower & Upper & $\begin{array}{l}\text { Wald } \\
\text { Chi- } \\
\text { Square }\end{array}$ & $\mathrm{df}$ & Sig. & \\
\hline \multirow{4}{*}{$\begin{array}{l}\frac{0}{0} \\
\frac{0}{0} \\
\frac{}{\Phi} \\
\stackrel{ }{ }\end{array}$} & [Smartphonne = ever] & -0.365 & 0.1746 & -0.707 & -0.022 & 4.361 & 1 & 0.037 & 0.659 \\
\hline & $\begin{array}{l}{[\text { Smartphonne }=\text { rarely }]} \\
{[\text { Smartphonne }=}\end{array}$ & -0.123 & 0.1736 & -0.464 & 0.217 & 0.504 & 1 & 0.478 & 0.884 \\
\hline & occasionally] & 0.227 & 0.174 & -0.114 & 0.568 & 1.708 & 1 & 0.191 & 1.255 \\
\hline & [Smartphonne = often] & 0.688 & 0.1783 & 0.338 & 1.037 & 14.887 & 1 & 0 & 1.99 \\
\hline \multicolumn{2}{|c|}{$\begin{array}{l}\text { [education }=\text { lower than collage }] \\
\text { [education }=\text { collage }]\end{array}$} & $\begin{array}{c}0.251 \\
0^{a}\end{array}$ & 0.1979 & -0.137 & 0.639 & 1.608 & 1 & 0.205 & $\begin{array}{c}1.285 \\
1\end{array}$ \\
\hline \multicolumn{2}{|c|}{$\begin{array}{l}\text { [purchase frequency }=\text { Low] } \\
\text { [purchase frequency }=\text { High] }\end{array}$} & $\begin{array}{c}-0.913 \\
0^{a}\end{array}$ & 0.201 & -1.307 & -0.519 & 20.651 & 1 & 0 & $\begin{array}{c}0.401 \\
1\end{array}$ \\
\hline \multicolumn{2}{|c|}{$\begin{array}{l}{[\text { age }=Y(16-35 y)]} \\
{[\text { age }=Y(36-52 y)]}\end{array}$} & $\begin{array}{c}-0.843 \\
0^{a} \\
1 b\end{array}$ & 0.2456 & -1.325 & -0.362 & 11.792 & 1 & 0.001 & 0.43 \\
\hline
\end{tabular}

Dependent Variable Smartphone; Model (Threshold), education, purchase frequency, age

a Set to zero because this parameter is redundant

$b$ Fixed at the displayed value

Sources: developed by the authors.

In the previous Table, the primary focus was on the value of $p$ independent variables, i.e. education, purchasing frequency and age (generation). Significant dependence has not been confirmed in the case of education. This variable was conditional on the major $\mathrm{H} 6$ hypothesis that was rejected. In the other two cases, the variables were evaluated as statistically significant. Thus, the $\mathrm{H} 7$ and $\mathrm{H} 8$ hypotheses were accepted, which allowed confirming a significant difference in purchasing frequency and age (generation). In the analysis of the dependency variable category, significance versus the reference variable was confirmed at «ever» and "often» and in both cases, the coefficient was less than 1. Thus the smartphone preference defined as «ever» and «often» have a lower level than «always».

Table 9. Output - ordinal analysis model

\begin{tabular}{ccccc}
\hline Variable & Category & $\beta$ & $\operatorname{Exp}(\beta)$ & Probability \\
\hline \multirow{2}{*}{ Purchase frequency } & Low & -0.913 & 0.4 & $28.60 \%$ \\
& High & 0.913 & 2.5 & $71.40 \%$ \\
\hline \multirow{2}{*}{ Age (generation) } & $\mathrm{Y}(16-35 \mathrm{y})$ & -0.843 & 0.4 & $31.10 \%$ \\
& $\mathrm{X}(36-52 \mathrm{y})$ & 0.843 & 2.3 & $69.90 \%$ \\
\hline
\end{tabular}

Sources: developed by the authors.

The previous table gives the exact expressions of the categories of independent variables to the reference categories, and therefore the option "always». The first is to describe the variable of the purchasing frequency. Customers who have a high shopping rate say that they use the smartphone "always», 2.5 times more often than customers with a lower shopping rate do. Customers who often purchase products are more likely to be open to new shopping opportunities and to the ability to shop anytime, anywhere using a smartphone. Customers with higher purchasing frequencies are likely to have more experience and lower concerns about using new platforms. A randomly selected customer will use the smartphone «always» with a probability of $71.4 \%$, while a customer with a low purchasing rate is only likely to be $28.6 \%$. In the case of focus on generations, it was observed a very unusual reality - a higher preference for the smartphone in the older generation. Generation $\mathrm{X}$ indicated that «always» uses the 

Differences

smartphone 2.5 times more often than Generation $Y$. The likelihood of using «always» a smartphone with a randomly selected $X$ customer is almost seventy per cent, while for the $Y$ generation is just a $30.1 \%$ probability. Although these results may seem unusual, they are evidence that older customers are also open to new forms of purchasing goods, and that businesses should not forget the needs of this consumer segment in their business and marketing strategies.

Conclusions. Nowadays, the most popular interactive medium of the present, the Internet, has broadened the perception and character of the economy as a whole. The use of this network has marked all those who have begun to perceive its innumerable possibilities and benefits. With its development, there is also an enormous increase in technologies supporting electronic processes, which are definitely included in e-commerce and all its forms inherent in it. The purpose of this paper was to identify consumer preferences for the use of digital devices to search for product information as well as the process of making purchases via the Internet. In line with the above presented results of the analysis, it can be stated that while smartphones are becoming a common device for performing various online activities, Slovak (as a representative sample of the assumptions model), consumers prefer the notebook, which is still popular.

In the first step, the device preference was analyzed with the conclusion that preferences are not homogeneous. As it was mentioned, the notebook reached the highest score. The middle category included the smartphone, tablet and desktop. For tablets, but especially for smartphones, it is expected a rising trend, and on the other hand, for desktops declining preferences. The other category included the phablet and PDA with the lowest preference. The second research question focused on the difference in the preferences of women and men in using smartphones, tablets, laptops and desktops. The only significant discrepancy occurred in the case of the laptop. Compared to men, women are more likely to prefer notebooks. The last step of the survey was to analyze the impact of education categories, purchasing frequencies, and age (generation) on customized smartphone preferences. The impact of differences is reflected in purchasing frequency and age (generations). Consumers of Generation X always buy smartphones with a higher purchasing frequency. Research data from comScore (2017) shows that most consumers prefer multiplatform, that is, accessing websites via the smartphone and desktop, so businesses should be able to respond to all devices. The fact is that while the use of smartphones is appropriate for some activities such as social media, for instant messaging or communication, most consumers prefer desktop for purchasing. For this reason, e-commerce operators need to monitor the distribution of consumers using mobile and desktop devices. Google Analytics is a good solution for how to do this. Nowadays, there is no doubt that innovations are synonymous with success. Thus, it is crucial to take advantage of all opportunities to strengthen customer relationships, and that the real opportunity lies in knowing relevant data that helps marketers focus more accurately on the right group of people. According to Hasan (2010), a better understanding of the behaviour of consumers, purchasing through the Internet is essential in creating and designing effective websites that can help businesses attract and retain consumers. For this reason, it is necessary to reflect the new trends brought by the market, which also opens the opportunity from the point of view of the customer to simplify the purchasing process, which uses different digital devices. The competitive struggle by market players also moves forward the implementation of innovations in the online store. These innovations are passed onto the market through the acquisition process. Depending on when consumers begin to apply innovations, Rogers (2003) divided them into five categories. For businesses, a desirable group of people is referred to as early adopters. These individuals have the highest degree of leadership, the most remarkable ability to influence other people's opinions, higher social status, financial liquidity, or higher levels of education. The other desired group is the Early Majority. These people acquire innovations a little bit more than average but sooner than early adopters and have an above-average social status. In this context, it is essential to reflect on the issue, what is actually the source of innovation development. Are consumers looking for new products or innovative businesses trying to convince the market of the inevitable need for new products? 
Author Contributions: Conceptualization, R. F., M. O. and B. G.; methodology, R. F. and R. B.; validation, R. B., and B. G.; formal analysis, R. F.; investigation, M. O.; resources, B. G.; data curation, R. F. and M. O.; writing - original draft preparation, M. O. and R. B.; writing - review and editing, R. B., B. G. and M. O.; visualization, R. F.; supervision, R. B. and B. G.; project administration, R. B., R. F. and B. G.; funding acquisition, R. B., R. F. and M. O.

Funding: This article is one of the partial outputs under the scientific research grant VEGA 1/0694/20 - Relational marketing research - the perception of e-commerce aspects and its impact on purchasing behaviour and consumer preferences and VEGA 1/0609/19 - Research on the development of electronic and mobile commerce in the aspect of the impact of modern technologies and mobile communication platforms on consumer behaviour and consumer preferences.

\section{References}

Agrebi, S., \& Jallais, J. (2015). Explain the intention to use smartphones for mobile shopping. Journal of retailing and consumer services, 22, 16-23. [Google Scholar] [CrossRef]

Almeida, F., Almeida, J., \& Mota, M. (2019). Perceptions and Trends of Booking Online Payments in Tourism. Journal of Tourism and Services, 10(18), 1-15. [Google Scholar] [CrossRef]

Arsenault, P. M. (2004). Validating generational differences. Leadership \& Organization Development Journal. [Google Scholar] [CrossRef

Bacík, R., Szabo, Z. K., \& Fedorko, R. (2014). The Analytical Insight Into Customer Perception Of Quality Determinants Of The E-Commerce Model Business-To-Consumer Subjects In The Central European Countries. Quality Innovation Prosperity, 18(2), 1526. [Google Scholar] [CrossRef]

Bae, S., \& Lee, T. (2011). Gender differences in consumers' perception of online consumer reviews. Electronic Commerce Research, 11(2), 201-214. [Google Scholar] [CrossRef]

Bang, Y., Han, K., Animesh, A., \& Hwang, M. (2013, July). From Online to Mobile: Linking Consumers' Online Purchase Behaviors with Mobile Commerce Adoption. In PACIS (p. 128). [Google Scholar]

Bhasker, B. (2013). Electronic commerce: framework, technologies and applications. Tata McGraw-Hill Education. [Google Scholar]

Chaffey, D. (2009). E-business and E-commerce management. Strategy, implementation and practice, Pearson Education, London.

Chong, A. Y. L. (2013). Mobile commerce usage activities: The roles of demographic and motivation variables. Technological Forecasting and Social Change, 80(7), 1350-1359. [Google Scholar] [CrossRef]

ComScore. (2017). Mobile Marketing Statistics compilation. Retrieved from [Link]

Deloitte. (2014). How digital technology is transforming health and social care. Retrieved from [Link]

DESI. (2020). Use of internet services. Retrieved from [Link]

Doherty, N. F. \& Chadwick, F. (2010). Internet retailing: the past, the present and the future. International Journal of Retail \& Distribution Management, 38(11/12), 943-965. [CrossRef]

Doolin, B., Dillon, S., Thompson, F., \& Corner, J. L. (2005). Perceived risk, the Internet shopping experience and online purchasing behavior: A New Zealand perspective. Journal of Global Information Management (JGIM), 13(2), 66-88. [Google Scholar] [CrossRef]

Fuentes, C., Bäckström, K., \& Svingstedt, A. (2017). Smartphones and the reconfiguration of retailscapes: Stores, shopping, and digitalization. Journal of Retailing and Consumer Services, 39, 270-278. [Google Scholar] [CrossRef]

Gefen, D. (2002). Customer loyalty in e-commerce. Journal of the association for information systems, 3(1), 2. [Google Scholar] [CrossRef]

Ghose, A., Goldfarb, A., \& Han, S. P. (2013). How is the mobile Internet different? Search costs and local activities. Information Systems Research, 24(3), 613-631. [Google Scholar] [CrossRef]

Global Web Index. (2017). Buying Online is Now Mobile-First. Retrieved from [Link]

Goh, K. Y., Chu, J., \& Wu, J. (2015). Mobile advertising: an empirical study of temporal and spatial differences in search behavior and advertising response. Journal of Interactive Marketing, 30, 34-45. [Google Scholar] [CrossRef]

Goldsmith, R. E., \& Goldsmith, E. B. (2002). Buying apparel over the Internet. Journal of Product and Brand Management, 11(2) 89-102. [Google Scholar] [CrossRef]

Groß, M. (2015a). Exploring the acceptance of technology for mobile shopping: an empirical investigation among Smartphone users. The International Review of Retail, Distribution and Consumer Research, 25(3), 215-235. [Google Scholar] [CrossRef]

Groß, M. (2015b). Mobile shopping: a classification framework and literature review. International Journal of Retail \& Distribution Management, 43(3), 221. [Google Scholar] [CrossRef]

Haji, M. N. (2014). A study of the impact of social media on consumers. International Journal of Market Research, 56(3), 387- 
Haque, A., Sadeghzadeh, J., \& Khatibi, A. (2006). Identifying potentiality online sales in Malaysia: A study on customer relationships online shopping. Journal of Applied Business Research (JABR), 22(4). [Google Scholar] [CrossRef]

Hart, C., Farrell, A. M., Stachow, G., Reed, G., \& Cadogan, J. W. (2007). Enjoyment of the shopping experience: Impact on customers' repatronage intentions and gender influence. The Service Industries Journal, 27(5), 583-604. [Google Scholar [CrossRef]

Hasan, B. (2010). Exploring gender differences in online shopping attitude. Computers in Human Behavior, 26(4), 597-601. [Google Scholar] [CrossRef]

Hu, X., Ocloo, C. E., Akaba, S., \& Worwui-Brown, D. (2019). Effects of business to business e-commerce adoption on competitive advantage of small and medium-sized manufacturing enterprises. Economics and Sociology, 12(1), 80- 99. doi:10.14254/2071-789X.2019/12-1/4

Hwang, W., Jung, H. S., \& Salvendy, G. (2006). Internationalisation of e-commerce: a comparison of online shopping preferences among Korean, Turkish and US populations. Behaviour \& information technology, 25(1), 3-18. [Google Scholar] [CrosRef]

Islam, M. Z., Low, P. K. C., \& Hasan, I. (2013). Intention to use advanced mobile phone services (AMPS). Management Decision, 51(4), 824. [Google Scholar] [CrossRef]

Jackson, L. A., Zhao, Y., Qiu, W., Kolenic III, A., Fitzgerald, H. E., Harold, R., \& von Eye, A. (2008). Culture, gender and information technology use: A comparison of Chinese and US children. Computers in human behavior, 24(6), 2817-2829. [Google Scholarl [1CrossRef

Kaplan, L. B., Szybillo, G. J., \& Jacoby, J. (1974). Components of perceived risk in product purchase: A cross-validation. Journal of applied Psychology, 59(3), 287. [Google Scholar] [CrossRef]

Klepochova, D., \& Kopanicova, J. (2012). Generacie X, Y a trvalo udržatel'na spotreba. Hodnoty, postoje a ich zobrazenie v spotrebitel'skom spravaní.

Kotler, P., \& Armstrong, G. (2004). Marketing. Praha: Grada, 2004. 855 s

Kozacka, P. (2014). Demografické zmeny - bližiaca sa pohroma pre organizacie. [Link]

Li, M., Dong, Z. Y., \& Chen, X. (2012). Factors influencing consumption experience of mobile commerce: A study from experiential view. Internet Research: Electronic Networking Applications and Policy, 22(2), 120-141. [Google Scholar] [CrossRef]

Liang, T. P., \& Turban, E. (2011). Introduction to the special issue social commerce: a research framework for social commerce. International Journal of electronic commerce, 16(2), 5-14. [Google Scholar] [CrossRef]

Mifsud, L. (2004). Research in the use of handheld technologies in compulsory education: A review of literature. Agder University College, Dept. of Information Systems, Kristiansand, Norway. [Google Scholar]

Ministerstvo Skolstva, vedy, vyskumu a sportu Slovenskej Respubliky. (2018). Výrocné spravy o stave vysokého Skolstva. Retrieved from [Link]

Mishchuk, H., Bilan, Y., \& Pavlushenko, L. (2016). Knowledge management systems: issues in enterprise human capital management implementation in transition economy. Polish Journal of Management Studies, 14(1), 163-173. DOI: 10.17512/pjms.2016.14.1.15

Mitra, S., Dangwal, R., Chatterjee, S., Jha, S., Bisht, R. S., \& Kapur, P. (2005). Acquisition of computing literacy on shared public computers: Children and the «hole in the wall». Australasian Journal of Educational Technology, 21(3). [Google Scholar] [CrossRef]

Mueller, J., Hutter, K., Fueller, J., \& Matzler, K. (2011). Virtual worlds as knowledge management platform-a practiceperspective. Information Systems Journal, 6(21), 479-501. [Google Scholar] [CrossRef]

Osman, S., Yin-Fah, B. C., \& Hooi-Choo, B. (2010). Undergraduates and online purchasing behavior. Asian Social Science, 6(10), 133-146. [Google Scholar] [CrossRef]

Paynter, J., \& Lim, J. (2001). Drivers and impediments to e-commerce in Malaysia. Malaysian Journal of Library \& Information Science, 6(2), 1-19. [Google Scholar]

Pescher, C., Reichhart, P., \& Spann, M. (2014). Consumer decision-making processes in mobile viral marketing campaigns. Journal of interactive marketing, 28(1), 43-54. [Google Scholar] [CrossRef]

Potosky, D. (2007). The Internet knowledge (iKnow) measure. Computers in Human behavior, 23(6), 2760-2777. [Google Scholar]

Roudposhti, V.M., Nilashi, M., Mardani, A., Streimikiene, D., Samad, S., \& Ibrahim, O. (2018). A new model for customer purchase intention in ecommerce recommendation agents. Journal of International Studies, 11(4), 237-253. doi:10.14254/20718330.2018/11-4/17

Rogers, E. M. (2003). Diffusion of innovation. 5th ed. The Free Press, Ny.Y.

Statista. (2017). When purchasing products or services, how often do you use the following device. Retrieved from [Link]

Stefko, R., Habanik, J., \& Butoracova-Sindleryova, I. (2010). Marketing instrumentary in the process of project acceptation within the acceleration of back-warded regions development (Slovak title below). Ekonomický casopis (Journal of Economics), 5(58), 512-526. [Google Scholar]

Sultan, F., Rohm, A. J., \& Gao, T. T. (2009). Factors influencing consumer acceptance of mobile marketing: a two-country study of youth markets. Journal of Interactive Marketing, 23(4), 308-320. [Google Scholar] [CrossRef 
R., Bacik, B., Gavurova, R., Fedorko, M., Olearova. Using Digital Devices in the Online Shopping: a Study of Demographic Differences

Yang, K. (2012). Consumer technology traits in determining mobile shopping adoption: An application of the extended theory of planned behavior. Journal of Retailing and Consumer Services, 19(5), 484-491. [Google Scholar] [CrossRef]

Yang, K., \& Kim, H. Y. (2012). Mobile shopping motivation: An application of multiple discriminant analysis. International Journal of Retail and Distribution Management, 40(10), 778-789. [Google Scholar] [CrossRef]

Zhang, Y. (2005). Age, gender, and Internet attitudes among employees in the business world. Computers in Human Behavior, 21(1), 1-10. [Google Scholar]

Zhou, L., Dai, L., \& Zhang, D. (2007). Online shopping acceptance model-A critical survey of consumer factors in online shopping. Journal of Electronic commerce research, 8(1). [Google Scholar]

Радован Бачик, Ph.D., дочент, Пряшівський університет у Пряшеві, Словаччина

Беата Гавурова, Ph.D., професор, Технічний університет у Кошице, Словаччина

Річард Федорко, Ph.D., доцент, Пряшівський університет у Пряшеві, Словаччина

Марія Олеарова, Пряшівський університет у Пряшеві, Словаччина

Використання цифрових технологій під час онлайн-шоппінгу: демографічні фактори

У статті проаналізовано вплив нових цифрових каналів комунікації на купівельну поведінку споживачів в онлайн-середовищі. Метою статті є дослідження переваг цифррових комунікаційних платформ для здійснення покупок в Інтернеті. Авторами визначено, що основними пристоями для онлайн-комунікації 6 смартфони, планшети, фаблети, лептопи, палмтопи та настільні комп'ютери. Детерміновану вибірку даних сформовано на основі результатів опитування 414 респондентів. Авторами систематизовано основні фактори, що впливають на вибір присторю для онлайн-комунікаці: гендер, вік, рівень освіти та частота покупок. Методологічним інструментарієм дослідження є непараметричні тести та регресійний аналіз з використанням порядкоих змінних. Емпіричні результати аналізу засвідчили, що Словаччина має відносно високий потенціал розвитку онлайн-торгівлі. Автороами наголошено на відсутності статистично значущого впливу гендерних відмінностей при виборі пристрою для онлайн-комікації. Так, визначено, що найбільш популярним пристроєм для здійснення онлайн-покупок серед чоловіків та жінокє лептоп. У статmі доведено, що розвиток інноваційних технологій забезпечить зростання рівня популярності серед споживачів викорситання планшетів та мобільних пристроїв при здійсненні олнайн-покупок. Результати аналізу підтвердили гіпотезу, що споживачі покоління $X$ надають перевагу мобільним пристроям для здійснення покупок в Інтернеті. Результати дослідження мають практичне значення і можуть бути викорситанні бізнес-сектором при розробленні ефективної стратегії цифрового мракетингу. Авторами зазначено, що підприємства, які викорситовують у соїй діяльності цфрові канали комунікації зі споживачами мають більший рівень лояльності, а отже й можливості підвищення рівня прибутковості. У статmі наголошено про необхідність подальших досліджень щодо визначення особливостей поведінки споживачів у онлай-середовищі.

Ключові слова: цифрові пристрої, електронний бізнес, онлайн-торгівля, Словаччина, покоління, регресійний аналіз, непараметричні тести.

Manuscript received: 12.02.2020

(C) The author(s) 2020. This article is published with open access at Sumy State University

Marketing and Management of Innovations, 2020, Issue 4

http://mmi.fem.sumdu.edu.ua/en 